\title{
Value co-destruction: exploring the role of actors' opportunism in the B2B context
}

\section{Article}

Accepted Version

Creative Commons: Attribution-Noncommercial-No Derivative Works 4.0

Pathak, B., Ashok, M. and Tan, Y. L. (2020) Value codestruction: exploring the role of actors' opportunism in the B2B context. International Journal of Information Management, 52. 102093. ISSN 0268-4012 doi: https://doi.org/10.1016/j.ijinfomgt.2020.102093 Available at https://centaur.reading.ac.uk/88809/

It is advisable to refer to the publisher's version if you intend to cite from the work. See Guidance on citing.

To link to this article DOI: http://dx.doi.org/10.1016/j.ijinfomgt.2020.102093

Publisher: Elsevier

All outputs in CentAUR are protected by Intellectual Property Rights law, including copyright law. Copyright and IPR is retained by the creators or other copyright holders. Terms and conditions for use of this material are defined in the End User Agreement.

\section{www.reading.ac.uk/centaur}

\section{CentAUR}

Central Archive at the University of Reading 
Reading's research outputs online 


\section{VALUE CO-DESTRUCTION: EXPLORING THE ROLE OF ACTORS' OPPORTUNISM IN THE B2B CONTEXT}

\section{ABSTRACT}

This exploratory study investigates value co-destruction in the Business-to-Business (B2B) context and examines the impact of actors' opportunistic behaviour on value co-creation. The research undertakes an in-depth case study based approach. It uses data triangulation, where multiple sources of evidence (interviews, conference audio recordings and documents) are collected from the case organisation (a vendor) and its service ecosystem partners in the ICT sector. The partners included in the study are distributors, channel partners, competitors, and customers. B2B alliances are driven by the motivations to maximise strategic value and minimise transaction cost. Thus, using the ecosystem lens, we find that actors' capabilities (resources and perceived value), vendor's approach to achieving strategic benefit and the channel governance mechanism enable value co-creation. However, using the transaction cost theory lens, we report that actors' opportunistic behaviour, technological disruptions and new business model challenges lead to value co-destruction (in the form of termination of relationship, conflict and business liquidation). Alliance partners need to evaluate the strategic benefits of collaboration, knowledge sharing, learning, trust building, market expansion and technology sharing, considering partners' self-serving behaviour driven by transaction cost economies. All ecosystem actors are seeking to develop capabilities, exhibit knowledge differentiators, demonstrate technology leadership, reduce uncertainty and respond to new business model challenges thus causing value co-destruction. Thus, this research is more encompassing because it explores factors that lead to both value co-creation and co-destruction.

\section{Keywords:}

alliances; data triangulation; opportunism; service ecosystem; thematic analysis; value cocreation; value co-destruction

\section{Introduction}

Value is increasingly co-created by multiple participants including firms, customers, suppliers, partners and other stakeholders (Vargo and Lusch, 2004; Ashok et al., 2014; 2016). Value co-creation (VCC) takes place within inter-organisational interactions, which may include dyadic relationships, value networks, and entire ecosystems. VCC is not limited to dyadic relationships, but extends to service ecosystems (Vargo and Lusch, 2016). The central point of a service ecosystem is to enhance VCC (Mele et al., 2010). This type of systemic, networked and ecosystem level perspective seems valuable, yet is seldom applied in the B2B co-creation research (Kohtamaki and Rajala, 2016).

Several research gaps and business needs underpin this research. Although, VCC is intrinsic to the customer's experience in a B2C context (Chuang and Lin, 2015), VCC is deemed as a value proposition in the B2B context (Kohtamaki and Rajala, 2016). Academic research of $\mathrm{VCC}$ in $\mathrm{B} 2 \mathrm{~B}$ context is a small fraction of the $\mathrm{VCC}$ research in the $\mathrm{B} 2 \mathrm{C}$ context (Lilien, 2016). Further, the significance of value co-creation in the B2B context has grown 
due to globalisation, digitalisation, servitisation, technological advances, market turbulence, and innovative business models (Cortez and Johnston, 2017).

Dismantling VCC into its constituent parts highlights the differences of VCC in B2B versus B2C context: "kind of value and for whom, kind of resources, kind of mechanism of resource integration" (Saarijavi et al., 2013:11). This paper, thus, responds to research gaps relating to the drivers of VCC and to the lack of understanding of VCC constituents in different contexts (McColl- Kennedy et al., 2012; Tommasetti et al., 2017).

Value co-creation is a dynamic yet complex process of assimilating, applying and transforming resources between ecosystems actors (Vargo and Lusch, 2011; Chuang and Lin, 2015; Senyo et al., 2019), where technological advances are not only facilitating VCC but also enabling innovative mechanism of resource integration (Saarijavi et al., 2013; Tommasetti et al., 2017). Since technology enables knowledge transfer (Ashok et al., 2016) and helps ecosystem actors to develop capabilities, it results in bounded rational behaviour.

Thus, collaborations don't always result in benefits for all the actors involved, in fact some alliances lead to destruction or diminishment of value for one or more actors - this concept is called value co-destruction (VCD) (Echeverri and Skalen, 2011; Ple, 2017). Despite the academic and business interest in VCC and VCD research, empirical investigation of factors influencing value co-destruction is lagging (Chowdhury et al., 2016; Cabiddu et al., 2019). Further, limited studies examine the role of actors' opportunistic behaviour (also called opportunism) in the B2B context, a gap addressed by this research.

According to transaction cost theory, contracts and transactions between ecosystem actors are affected by behavioural assumptions; and since firms seek to minimise economic transaction costs, they show bounded rationality and opportunistic behaviour. Unlike rationality, opportunistic behaviour is simple, self-centred, and a source of troublesome behaviour such as dishonesty and misinformation presented by actors in inter-firm relationships (Williamson, 1985; 2007). Such behaviour can generate challenges for ecosystems actors wishing to maximise gain in the turbulent B2B market (Cortez and Johnston, 2017; Martinez-Noya and Narula, 2018). This paper, thus explores alliances in the B2B context from the perspectives of both service ecosystems and transaction cost theory to explore the antecedents of value co-creation and co-destruction.

First, using the service ecosystems lens, this study explores the factors that enable B2B ecosystem actors to collectively create value. The VCC process helps organisations to screen partners for collaboration, reconfigure resources and technology, take advantage of partners' capabilities, enhance learning through alliances, and re-evaluate strategic position in the market (Maglio, 2017; Ramaswamy and Ozcan, 2018; Ashok, 2018). However, past studies have mostly focused on value co-destruction in the context of a firm and its customers, thus ignoring other actors in the ecosystem (Ostrom et al., 2015; Leclercq et al., 2016; Prior and Marcos-Cuevas, 2016), a research gap addressed by this study.

Second, using the transaction cost theory lens, this research examines the impact of actors' opportunistic behaviour on value co-creation/co-destruction in the B2B context. Transaction cost literature has long acknowledged that actors' opportunistic behaviour leads to diminishing value (Williamson, 1985; Wathne and Heide, 2000). Thus, it is not a surprise that many B2B alliances do not realise their full potential, fail to capture value and do not fully appreciate collaborative business practices (de Man and Luvison, 2019). 
Thus, this study investigates the determinants of value co-creation and co-destruction, an approach that makes this research more encompassing, less biased and closer to real business life (Ple, 2017; Cabiddu et al., 2019). In their literature review of the theory and practices of value co-creation in a B2B context, Kohtamaki and Rajala (2016) identify the need for a single case study approach to develop an in-depth understanding of the phenomenon. Thus, a comprehensive exploratory case study is adopted, involving an ICT vendor and its channel ecosystem actors in the B2B context. The research setting is very relevant because technological advances and volatile socio-economic-political conditions make ICT ecosystems dynamic and fiercely competitive (Basole et al., 2015). Further, research shows that main vendors in ICT ecosystems face challenges in enabling value co-creation and collaboration across their B2B network partners (Ritala et al., 2013).

Recent scholarly work in ICT (ICT-enabled) ecosystems have adopted in-depth case study methodology using data triangulation (multiple sources of data like qualitative interviews, company documents, workshop presentations) approach (Ritala et al., 2013; Jha et al., 2016); this study uses a similar methodology. Data triangulation enhances validity of the research process, improves reliability and credibility of the study results, and reduces bias (Eisenhardt and Graebner, 2007; Creswell, 2009; Bryman, 2016).

The paper is structured as follows: the next section discusses the theoretical background of value co-creation in the context of ecosystems and transaction cost theory. The following section presents a description of the case study and the research methodology. This is followed by the findings and discussion on value co-creation and value co-destruction in the B2B context. The final section concludes with the research contribution, limitations and future direction.

\section{Theoretical background \\ 2.1 Service ecosystem}

Value creation does not just take place through the activities of a single actor or between a firm and its customers but among a whole host of actors, where rules and regulations work as building blocks for the ongoing formation and reformation of increasingly complex assemblage (of ecosystem actors) (Vargo and Lusch, 2016: 9). These loosely coupled social economic actors are connected by shared institutional logic (Vargo and Lusch, 2008; Lusch and Nambisan, 2015). Such logic and arrangement may include ecosystem structure and its governance (Gulati et al., 2012; Vargo and Lusch, 2016). "A service ecosystem is a spontaneously sensing and responding spatial and temporal structure of largely loosely coupled value proposing social and economic actors interacting through institutions and technology, to: (1) coproduce service offerings, (2) exchange service offerings and (3) cocreate value" (Lusch, 2011: 15). However, the challenge is to govern and coordinate the actors involved in the VCC process.

Furthermore, scholars have used various terminologies to portray the ideas of an ecosystem, including: business ecosystem, innovation ecosystem, technology ecosystem (platform), and service ecosystem (Thomas and Autio, 2012; Aarikka-Sternroos and Ritala, 2017). The main ideas of these concepts are that ecosystem members co-evolve capabilities around a shared set of technologies and cooperate and compete to support new products and innovations (Moore, 1996; Vargo et al., 2017). The service-dominant logic theory explains 
the importance of service exchange and argues that VCC involves a symbiotic relationship between multiple actors from the ecosystem (Lusch and Nambisan, 2015). In the service ecosystem, value is co-created by exchange of service (application of competencies) among multiple actors (Vargo and Lusch, 2016). Where technological advances have fundamentally changed the mechanism of exchange of resources (and competencies) (Saarijavi et al., 2013) and opens up avenues for misuse of resources amongst network partners. We thus examine the determinants of value co-creation and co-destruction in the service ecosystem.

\section{2 (re)Conceptualising value co-creation and introducing co-destruction}

In this study, co-creation is defined as the participation of actors (organisation, customer, partner or other actors within a service ecosystem) in the development of a product or service through interaction and integration of resources (Ramaswamy and Gouillart, 2010; Gronroos and Voima, 2013; Ind et al., 2013; Ashok et al., 2018); and "value" as an outcome resulting from such co-creation processes and activities (Spohrer and Maglio, 2010), and value co-creation is (re)conceptualised as

An active, creative, and social interaction process based on the need or desire of actors linked together within a service ecosystem, who integrate their resources to support the various VCC activities such as idea generation, knowledge sharing, product development, solution implementation and to create win-win benefits.

Viewing alliances through the ecosystem lens, this study focuses on four key aspects of the VCC definition. First, based on need or desire of actors (Arnould, 2014; Hietanen et al., 2017): we study the actors' motivation for value co-creation. Second, actors are linked together within a service ecosystem (Vargo and Lusch, 2011; Ind et al., 2013): we evaluate if all the actors in a service ecosystem show active, creative and social engagement. Third, integration and alignment of resources to support VCC activities (Edvardsson et al., 2012; Skålén et al., 2015; Chou et al., 2016): we investigate how alliance partners combine and exchange resources for value co-creation and innovation. Fourth, we analyse the outcomes of VCC, as they are expected to create win-win benefits for all the actors in the ecosystem (Spohrer and Maglio, 2010).

Therefore, this study investigates the first research question (RQ1)

How do organisations and their ecosystem actors co-create value in the B2B context?

Significant literature is focused on the positive outcome of the resource integration of ecosystem actors, which leads to a win-win proposition (Spohrer and Maglio, 2010). However, negative results of this resource integration process are also manifest in win-lose, lose-win or lose-lose propositions, which are referred to as VCD. There are three major reasons why VCD emerges in an alliance. Firstly, factors impacting inter-firm relationship: mistrust, inadequate communication and coordination, scarce human capital, imbalance in power or competencies (Vafeas et al., 2016), and customer dissatisfaction with previous experience (Nam et al., 2018). Secondly, managerial challenges in the alliance: absence of information, inability to contribute due to fear of leakage, absence of clear expectations, partner's misbehaviour (Jarvi et al., 2018). Thirdly, the complex ecosystem boundaries between collaborating communities (Uppström and Lönn, 2017). The next section discusses how actors' behaviour can lead to VCC or VCD as underpinned by transaction cost theory. 


\subsection{Transaction cost theory and opportunism}

Transaction cost theory has served as the theoretical foundation for numerous studies in the B2B domain providing a host of empirical generalisations regarding both the costs of B2B transactions as well as means of effectively governing these costs (Jap et al., 2013; Rindfleisch, 2019). Transaction cost theory outlines two important assumptions about economic actors, namely: bounded rationality and opportunism. In the B2B context, partners' opportunistic behaviour will impact both transaction costs and the governance of alliance. Opportunistic behaviour typically focusses on the proclivity of exchange partners to engage in deceptive and self-serving behaviour. Williamson (1985: 47) defines opportunism:

Self-interest seeking with guile ... such as lying, stealing, and cheating. It refers to the incomplete or distorted disclosure of information, especially to calculated efforts to mislead, distort, disguise, obfuscate, or otherwise confuse.

Opportunism may manifest itself as a deliberate misrepresentation during relationship initiation (i.e. ex ante), and/or as violation over the course of the relationship (i.e. ex post). Luo (2006: 123) proposes two forms of opportunism: strong-form opportunism is characterised as a contractual norm violation, i.e. breaching terms, clauses, and conditions that are explicitly codified in a contract. Weak-form opportunism involves actions that violate relational norms, which are not detailed in a contract but represent shared understanding among all members.

Furthermore, opportunistic behaviour has the potential to cause redistribution of wealth created (Wathne and Heide, 2000), which can lead to diminishing value for the parties involved in value co-creation (Sarker et al., 2012). This is because opportunism restricts value creation in several ways (Masten, 1988; Chowdhury et al., 2016): it increases transaction and information costs, escalates conflicts between alliance partners (Wathne and Heide, 2000; Yigitbasioglu, 2014), hampers the development of reciprocity or repeated commitment and trust, and suppresses confidence in partner cooperation (Vafeas et. al, 2016; Bagheri et al., 2019). Thus, the failure to see beyond the short-term optimisation of selfinterest inhibits cooperative effort (Luo, 2006; Ertimur and Venkatesh, 2010), and leads to value co-destruction.

The transaction cost for an ecosystem actor to search, contact, and contract is expected to be high, thus inhibiting successful value creation (Williamson, 1985; Ketokivi and Mahoney, 2017). An intriguing issue is the implications of increased transaction costs of the myriad of partner's opportunistic behaviours in B2B context. Transaction cost theory also contemplates ways of enriching the challenges posed by today's rapidly shifting economic landscape from the perspectives of actors' behavioural assumptions. This research therefore uses transaction cost theory to explore the impact of actors' opportunism in the B2B value co-creation context. Therefore, this study investigates the second research question (RQ2),

What is the impact of actors' opportunistic behaviour on value cocreation/destruction in the $B 2 B$ context?

Figure 1 captures the conceptual model (a priori themes) based on literature review. The next section provides a narrative of the research methodology and the case organisation. 


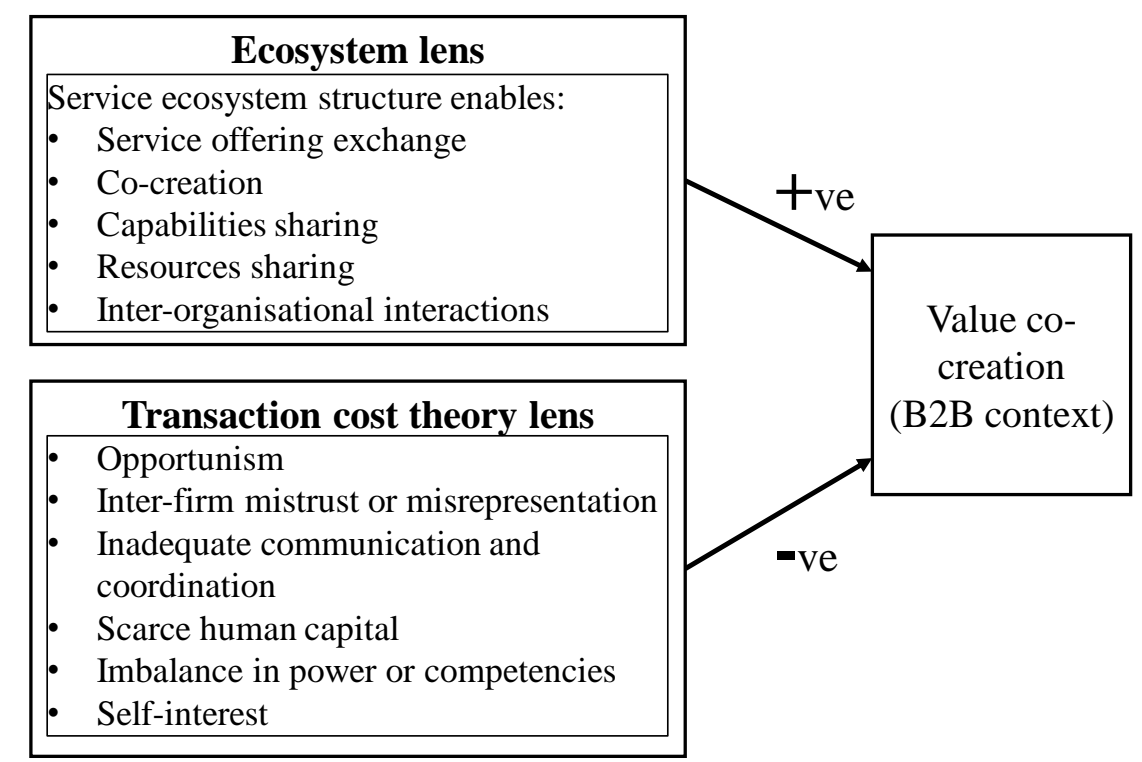

Figure 1: Conceptual model (a priori themes)

\section{Methodology and research context}

This exploratory study investigates (using the ecosystem lens) the factors that enable an ICT organisation and its ecosystem to co-create value in the B2B context, and examines (using the transaction cost theory lens) the impact of actors' opportunistic behaviour on value codestruction. Given the limited understanding of the determinants of VCC and VCD in service ecosystems (Ostrom et al., 2015; Neghina et al., 2015), we use an in-depth case study method (Yin, 2014; Jha et al., 2016). This approach facilitates the holistic study of organisational processes and inter-organisational relationships in the context of B2B alliances (Robson, 2002), and gives us the latitude to explore and construct new theory (Hartley, 2004).

The ICT ecosystem research context is extremely relevant in the current global and dynamic environment. This is because ICT ecosystems show increased coopetition, blurring of industry boundaries, tensions and dynamic relationship between ICT vendors (existing and new entrants) (Basole et al., 2015). Further, ICT ecosystems have difficulties in enabling collaboration across the network partners (Ritala et al., 2013).

In order to answer the research questions, it was fundamental to choose a case organisation with comprehensive access to its ecosystem partners. The advantages of a single case are commitment to intensity, ability to exploit opportunities, and exploration of a significant phenomenon under rare or extreme circumstances (Eisenhardt and Graebner, 2007; Creswell, 2009; Bryman, 2016; Kohtamaki and Rajala, 2016). The chosen case organisation is a hardware vendor, AlphaVendor (not its real name), in the ICT sector.

AlphaVendor is a successful multinational and global organisation (in 170+ countries) that offers information, service solutions, and telecommunication and networking equipment to customers through its ecosystem partners. Although AlphaVendor is comparatively new to the European market, it has managed to foster several alliances (over 50 partners in the UK in 2017-2018 alone). This success can be attributed to its approach to VCC, making it an ideal case organisation in which to investigate the phenomenon of value co-creation/codestruction. AlphaVendor has three areas of business: telecom carrier network, device manufacturing and enterprise business. This research focuses on AlphaVendor's Western 
European market and explores AlphaVendor's enterprise business (hardware equipment, software and services to enterprise customers), which provides B2B ICT products and solutions.

This research had exceptional access to AlphaVendor and its wider ecosystem, which included AlphaVendor's Partner Distributor, Channel Partners (which in turn include Value Added Partners/Resellers, Independent Software Vendor, and Training Academy), Academic Researcher, Competitors, Complementors, and B2B Customers. Other independent firms acting as AlphaVendor's ecosystem partners are involved in training, selling, extending and implementing hardware-based ICT solutions. This case study provided a unique opportunity to examine how AlphaVendor's alliance operates and how opportunistic behaviour leads to value co-destruction. In-depth access to AlphaVendor and its service ecosystem actors provided multiple sources of data for triangulation.

A two-stage research approach was taken. Stage 1 exploration involved AlphaVendor and its ecosystem actors, where data was collected and analysed from multiple sources: 13 interviews, four conference audio recordings and channel policy documents. Stage 2 validation involved five actors: complementary vendors, a competitor and an academic (five interviews) (Figure 2).

Utilisation of multiple sources for data collection (documents, audio recordings from conference presentations, and semi-structured interviews) over a prolonged period of engagement with the case organisation helped minimise possible limitations such as response bias and reflexivity (Yin, 2014). In total, data was collected from 18 interviews (13 from the AlphaVendor ecosystem, and five informants), four conference presentation recordings, and documentary sources. This approach of using several sources (like qualitative interviews, company documents, workshop presentations) for data triangulation is supported by recent empirical research in ICT (and ICT-enabled) ecosystems (Ritala et al., 2013; Jha et al., 2016).

The documentary evidence was collected between January 2017 and July 2018, and included AlphaVendor's channel policies, company websites and industry reports. These documents provided an overview of the company profile, channel business model, their policies and the role of individual actors in the ecosystem. They were transcribed and analysed in Nvivo.

AlphaVendor gave permission for the authors to attend two Channel Conferences held in July 2017 and May 2018 in London, which helped to understand their channel ecosystems and identify prospective interviewees. The authors had permission to record four presentations, which were transcribed and analysed to understand AlphaVendor and its ecosystem actors' strategy, products and services. The conference recordings included presentations by AlphaVendor's channel director, who explained AlphaVendor's channel roadmap for coming years (coded as AV_M1_CA); Channel Partner (coded as CP6_CA); and two Customers (coded as Cust2_CA and Cust3_CA) (see Table 1).

In Stage 1, thirteen in-depth semi-structured interviews (see Table 2 for profiles) were conducted in Western Europe between November 2016 and June 2018, of which eleven were face-to-face and two via Skype. The interviews lasted between 23 and 120 minutes (with an average of 59 minutes). They were conducted with senior executives in AlphaVendor (AV_M1, M2), Partner Distributor (PDist), Channel Partner organisations (CP1-CP5), their customers (Cust1), training academy (TA) and competitors (Comp_M1, M2). 


\section{RESEARCH DESIGN}

\section{Stage One - Exploration}

13 interviews

4 conference audio recordings

Channel policy documents
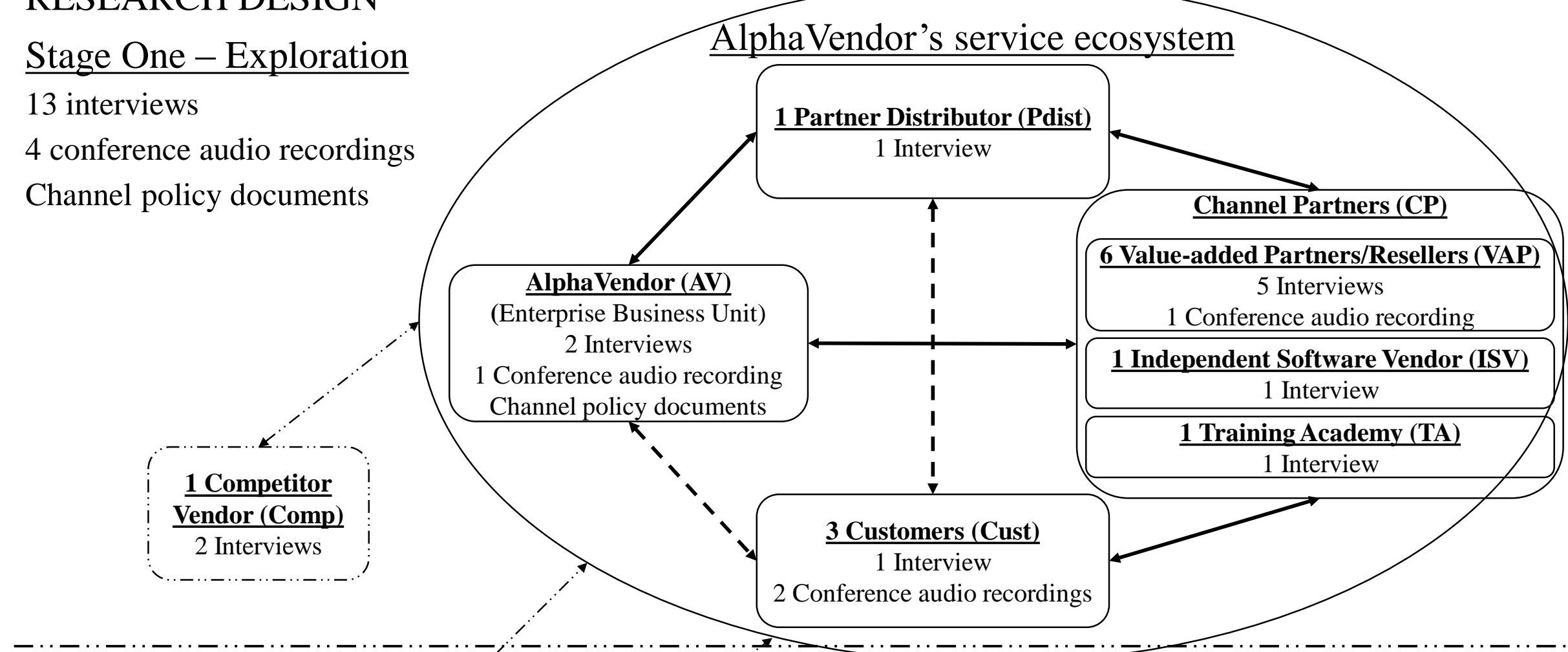

Stage Two - Validation

5 interviews

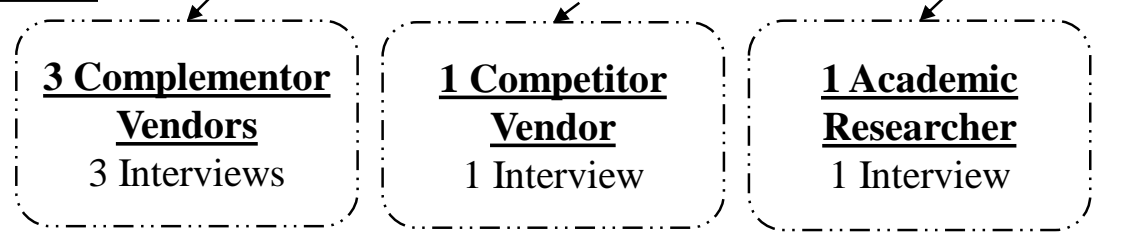

Direct-frequent

interaction between actors

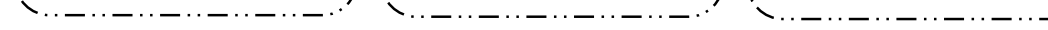

$\leftarrow$ Indirect-occasional

interaction between actors

Figure 2: Research design (AlphaVendor's service ecosystem actors), two-stage approach 
All informants had worked in the European market for several years. The competitors included (Stage 2) in the study represent a multinational IT organisation, which provides hardware, software and services to its customers; the organisation has significant presence in Europe. Thus, AlphaVendor operates in a highly competitive and global market place, where partners can easily switch to other ecosystems.

Table 1 Profile of conference audio presentations (audio recording lengths 17-21 minutes)

\begin{tabular}{|l|l|}
\hline $\begin{array}{l}\text { Organisation (Coded) } \\
\text { conference audio }(\boldsymbol{C A})\end{array}$ & Brief description of presenting organisation/actor and speaker \\
\hline AV_M1_CA & $\begin{array}{l}\text { Channel Director at original equipment manufacturer in ICT, } \\
\text { responsible for all enterprise partner channels programme and } \\
\text { development in UK }\end{array}$ \\
\hline CP6_CA & $\begin{array}{l}\text { Operations Director at network solution and systems provider, } \\
\text { equipment configuration and service management, UK-based } \\
\text { channel partner. }\end{array}$ \\
\hline Cust2_CA & $\begin{array}{l}\text { Technical Architect at UK-based broadband service provider, looks } \\
\text { after infrastructure and solutions development }\end{array}$ \\
\hline Cust3_CA & $\begin{array}{l}\text { Network and Technical Manager/engineer at UK higher education } \\
\text { institution; responsible for planning/managing systems }\end{array}$ \\
\hline
\end{tabular}

For the semi-structured interview, the elements of VCC definition (actors' resources and perceived value) proposed in section 2.2, and the core concepts of transaction cost theory and the role of ecosystem governance mechanism discussed in section 2.3 were utilised. The questions were shaped to help explore (Cabiddu et al., 2019) both positive and negative aspects of VCC practices within AlphaVendor's ecosystem.

In Stage 2 of the research, the findings from Stage 1 were validated with five informants, coded as In_1- In_5 (Sandelowski, 1998; Yin, 2014). Informants were selected based on their expert knowledge and experience (Cantrill et al., 1996) in value co-creation in a B2B context. Informants' interviews lasted between 25 and 51 minutes (with an average of 42 minutes). Table 2 presents their profiles.

The qualitative data collected in this research was analysed using thematic analysis, after reflecting on the potential advantages and disadvantages of this approach as discussed in Braun and Clarke (2006) and Boyatzis (1998). The study used six-phased thematic analysis as laid out by Braun and Clarke (2006), which involved familiarisation with data, generation of initial codes, searching-reviewing-defining themes, and producing the report. Themes were developed around predetermined (a priori) and emergent patterns (Stuckey, 2015).

The next section presents study findings that are based on a priori codes which are generated based on the VCC definition (e.g. resources and perceived value), ecosystem governance (e.g. Sarker et al. 2012; Jap et al., 2013) and various strong- and weak-form opportunism discussed in transaction cost theory (Williamson, 2007; Luo, 2006). The findings also present results that are generated from the emergent themes, such as nature of enterprise business model, technological disruptions and its challenges within the AlphaVendor ecosystem. 
Table 2 Profile of interviewees

\begin{tabular}{|c|c|}
\hline $\begin{array}{l}\text { Organisation } \\
\text { (Coded) }\end{array}$ & Brief description and interviewee profile \\
\hline \multicolumn{2}{|c|}{ Stage 1 - exploration interviews (interview lengths 23-120 minutes) } \\
\hline $\begin{array}{l}\text { AlphaVendor } \\
\text { (AV_M1) }\end{array}$ & $\begin{array}{l}\text { Channel Director at AlphaVendor; responsible for all enterprise partner channels } \\
\text { programme and development in UK }\end{array}$ \\
\hline$\left(\mathrm{AV} \_\mathrm{M} 2\right)$ & $\begin{array}{l}\text { Area Sales Manager at AlphaVendor responsible for managing key accounts in } \\
\text { southern England }\end{array}$ \\
\hline $\begin{array}{l}\text { Training } \\
\text { Academy } \\
\text { (TA) }\end{array}$ & $\begin{array}{l}\text { Executive Director at a higher education institution that provides training and } \\
\text { certification for AlphaVendor's products to industry people and students }\end{array}$ \\
\hline $\begin{array}{l}\text { Distributor } \\
\text { (PDist) }\end{array}$ & $\begin{array}{l}\text { Account Director of enterprise division at an IT Distributor organisation; } \\
\text { responsible for managing and developing AlphaVendor channel ecosystem }\end{array}$ \\
\hline $\begin{array}{l}\text { Channel } \\
\text { Partner } \\
\text { (CP1_M1) }\end{array}$ & $\begin{array}{l}\text { Co-founder and Director at an IT products and solutions provider; responsible } \\
\text { for business development in Western Europe }\end{array}$ \\
\hline (CP1_M2) & $\begin{array}{l}\text { Co-founder and Director at IT products and solutions provider; responsible for } \\
\text { worldwide operations management }\end{array}$ \\
\hline$(\mathrm{CP} 2)$ & $\begin{array}{l}\text { Director for Technical Services at a multi-vendor IT provider in the UK; } \\
\text { responsible for alliance with six key vendors }\end{array}$ \\
\hline (CP3) & $\begin{array}{l}\text { Sales Manager at an IT hardware and software service and solution provider in } \\
\text { the UK; responsible for AlphaVendor product business development }\end{array}$ \\
\hline (CP4) & $\begin{array}{l}\text { Strategic alliance business development director at a ICT company; responsible } \\
\text { for AlphaVendor alliance and partner business development in UK and Europe }\end{array}$ \\
\hline (CP5) & $\begin{array}{l}\text { Partner and alliances manager at a software-based storage products provider; } \\
\text { responsible for developing partner programmes and leading alliances with } \\
\text { distributors and vendors }\end{array}$ \\
\hline $\begin{array}{l}\text { Customer } \\
\text { (Cust1) }\end{array}$ & $\begin{array}{l}\text { Network Operations Director at a UK-based Internet Service Provider; } \\
\text { responsible for managing network infrastructure and ensuring service quality }\end{array}$ \\
\hline $\begin{array}{l}\text { Competitor } \\
\text { (Comp_M1) }\end{array}$ & $\begin{array}{l}\text { Internet of Things Alliance director at a MNC; responsible for developing and } \\
\text { managing alliances in Western European market }\end{array}$ \\
\hline (Comp_M2) & $\begin{array}{l}\text { Senior Manager, Worldwide Distribution, responsible for distribution of } \\
\text { products and services and alliance relationship across Europe }\end{array}$ \\
\hline \multicolumn{2}{|c|}{ Stage 2 - validation interviews (interview lengths 25-51 minutes) } \\
\hline $\begin{array}{l}\text { Informant } \\
\text { In_1 }\end{array}$ & $\begin{array}{l}\text { 10+ years of management consulting experiences in co-creation practices in IT } \\
\text { project and security management in EMEA. Regular speaker at industry } \\
\text { conferences }\end{array}$ \\
\hline In_2 & $\begin{array}{l}\text { Operations and Programme Director at a global cloud service provider; formerly } \\
\text { worked in the UK B2B market; 14+ years of experience in IT and management } \\
\text { consultancy }\end{array}$ \\
\hline
\end{tabular}




\begin{tabular}{|l|l|}
\hline $\begin{array}{l}\text { Organisation } \\
\text { (Coded) }\end{array}$ & Brief description and interviewee profile \\
\hline In_3 & $\begin{array}{l}\text { Business Analytics Consultant at one of the fast-growing big-data solutions } \\
\text { providers in the UK. 13 years of experience (including working with enterprise } \\
\text { vendors in the UK market as a partner) }\end{array}$ \\
\hline In_4 & $\begin{array}{l}\text { Senior Cyber Security Consultant at a global consulting firm; } 15+\text { years of } \\
\text { experience in the UK and EMEA; holds expertise on VCC between all actors. }\end{array}$ \\
\hline In_5 & $\begin{array}{l}\text { Associate Professor in Marketing and Service Management at a UK Business } \\
\text { School; 15 years of research experience }\end{array}$ \\
\hline
\end{tabular}

\section{Results}

This study analysed channel policy documents, audio recordings and interview transcripts to identify the determinants of VCC and VCD in the B2B context in the ICT sector. A priori themes from literature review were amended to construct detailed factors leading to VCC and VCD amongst service ecosystem partners. The findings of this study show that B2B alliances are driven by the motivation to maximise value and minimise transaction costs. In response to RQ1, using the ecosystem lens, we find that VCC occurs through a combination of actors' capabilities (resources and perceived value), vendor's approach to achieving strategic benefit and the service ecosystem's channel governance mechanism. In response to RQ2, using the transaction cost theory lens, we highlight that value co-destruction happens as a result of actors' opportunism, technological disruptions and new business model challenges.

\subsection{Value co-creation in B2B context}

\subsubsection{Actors' capabilities (resources and perceived value)}

Evidence from the case organisation emphasises that AlphaVendor's go-to-market model is through its channel partners/distributors, i.e. there is no direct selling to customers. This model, therefore, necessitates value co-creation among the ecosystem actors in order to deliver products and services to business customers. Some of the leading ICT hardware vendors focus on high-quality products/services, such as networking devices, service storage, security, cloud, data centre equipment, switches, and routers, with a keen eye on reliability, scalability, compatibility, performance and security. The roles of the actors involved in the B2B enterprise service ecosystem are summarised below:

- Vendor: the main organisation that manufactures products and offers services through a network of other companies in an alliance.

- Distributor: an independent organisation involved in maintaining the supply of products manufactured by the vendors, developing and managing the sales channel (channel partners).

- Channel partner $(C P)$ : an independent organisation in partnership with the vendors and distributors to market and sell the products manufactured by the vendor.

- Value Added Partners (VAP) or Value Added Reseller (VAR): also considered as a channel partner; they have greater commitment to the vendor and have bigger sales targets. The VAP can perform joint customisation and innovation with the vendor. 
- Independent software vendor (ISV): an organisation that develops, sells and markets software that usually complements vendor-manufactured products. ISVs are also included in the sales channel and are managed under channel partner policy.

- Training Academy: an organisation that provides training and certification related to vendor's products and services. Can be a channel partner or an independent organisation with the resources and skills to provide specialised courses on vendor's products and services.

All these actors are also part of the Vendor's sales or channel ecosystems; according to AV_M1: "Nobody can do everything [in] IoT and Cloud, [Vendors] fundamentally rely on an ecosystem, which includes ISV partners, distributors, channel partners and even customers".

As vendor-partner agreement is not exclusive, alliance partners need to be able to work with collaborators and competitors at the same time. For example, distributors and channel partners are free to sell the products and services of any vendor, and free to join or leave a vendor's service ecosystem. Figure 3 (using the ecosystem lens) captures how actors' resource integration and perceived value enable the ecosystem to co-create value.

The findings suggest that the vendor brings innovative products, $R \& D$ capability and expertise. AlphaVendor operates a two-tier partnership: tier 1 with the distributor and tier 2 with the channel partners including VAR, ISVs, Resellers, and TAs. The distributor manages stock from the vendor and manages and provides credit lines to the channel partners. Channel partners in turn bring business (customers) to the distributor and vendor.

We find existence of various forms of co-creation such as co-conception of ideas, codesign, and co-marketing, which is enabled by the frequent resource interactions amongst ecosystem partners. Further, each actor has a unique perceived value within the ecosystem, which enables VCC. For example, while AlphaVendor focused on market share and knowledge, the distributor looked at product portfolio and development funds, while the channel partner dedicated funds for innovation, marketing and developing product expertise, and finally the customers contributed to innovation through customisation and quality.

We report that AlphaVendor is co-creating value with its ecosystem partners based on the following operant resources developed over time with its partner organisations:

- Competitive price, product range, quality and reliability of products

- Cost advantage

- Vendor's research and development capability

- Vendor's and distributor's support to partners

- Vendor's training academy programme that promotes knowledge sharing amongst partners We specifically note AlphaVendor's ambition to go beyond its sales channel to create a wider ecosystem around its products. AlphaVendor reaches and influences a broader range of stakeholders through its training academy programme; for example, it encourages student engagement with its products through free courses. Such initiatives create stronger brand and challenge competitors. 


\section{Pdist's Resources}

\section{- CP base}

-Stock management

- Credit line support

-Technical/Sales support

-Strong reputation in channel

ï̄', ' Perceived Value

Growing market share-revenue

Enjoys loyalty from Pdist, CPs

- Innovative ideas

- Market knowledge-expertise

- Continuous feedback loop

- Reduced risk of failure

\section{AV's Resources}

- Brand, Innovation, R\&D

-Price, Range, Quality

-Incentives \& support

- Partner development fund

-Knowledge sharing

- Global presence
- Regional market knowledge

- Global presence

CPs
$\vdots$
$\vdots$

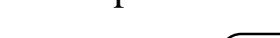

\section{Partner}

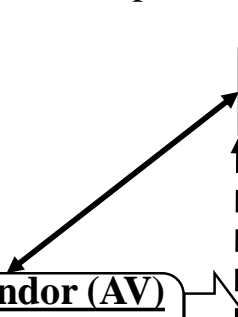

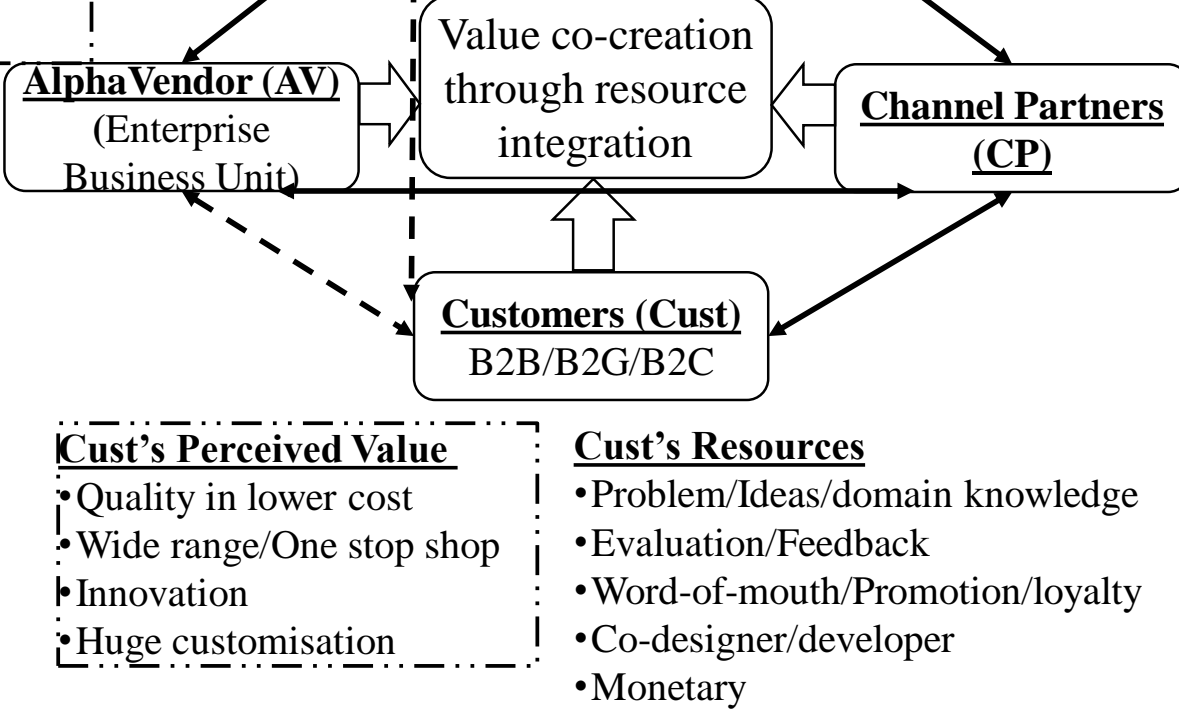
Distributor (Pdist)

Value co-creation through resource

\section{.} Pdist's Perceived Value

- Wide product portfolio

Price, Quality, Durability

- Handsome \% of bonus, margin

- Training \& certification

- Funds for business

development

$-\cdots-\cdots-\cdots-$

\section{CP's Resources}

- Customer base, Sales force

-Cultural/Local-market expertise

- Add-ons and extensive consulting

- Customer support

- Specialised expertise (e.g. design skills)

- Customer trust

\section{CP's Perceived Value}

- Wide product portfolio

- Quality, Durability

- Lower cost to join

- Attractive margin

† Training \& certification

- Funds for innovation and marketing

-Wide access to market

Experience in variety of products

$\longleftrightarrow$ Direct-frequent

interaction between actors

- Monetary

$\leftarrow$ Indirect-occasional

interaction between actors

Figure 3: VCC in B2B context, actors' resources and perceived value 
4.1.2 Vendor's approach to achieving strategic benefit and channel governance mechanism We found evidence of three types of governance mechanism that play a pivotal role in enabling VCC between AlphaVendor and its ecosystem partners.

- Contractual agreement: First, AlphaVendor's ecosystem actors depend on contractual agreements that provide a written commitment; as explained by two interviewees: "written agreements ensure that everybody does things in the right way" (CP3); and "when something is in writing, it's followed" (AV_M1). These contracts lay down the fundamentals of AlphaVendor and its ecosystem partner relationship, such as actors' roles and responsibilities, resource commitment, processes, rewards, service-level agreements, non-disclosure agreements and channel policy. Second, AlphaVendor uses formal channel policies and frameworks to sell and promote its products and partnership. It also establishes team agreements for individual projects in order to capture project-specific commitments not detailed in an NDA or partner agreement. Several interviewees highlighted the significance of the contractual agreement, for example Comp_M1 argued, "It looks like just a page, but contracts are essential. The contract needs to be simple and at the same time it protects you [Vendor] and protects them [Partners]".

- Criteria for membership and incentives: Secondly, AlphaVendor strictly regulates the admission of new members/partners to its channel ecosystem. Its ecosystem membership is divided into business functions, annual revenue, certification, staff and other general requirements, captured in its Western Europe Channel Handbook. For example, the distributor needs to meet a $\$ 10$ million annual sales target, and in return AlphaVendor provides the distributor with a very healthy margin and rebate. For example, the distributor interviewee said, "with AlphaVendor we have to add more value, so we can justify a healthier margin" (PDist). The Channel Handbook also specifies a benefits and rewards mechanism to attract members to the channel partnership. All Tier 1 and Tier 2 partners have access to a training fund. However, rewards are allocated according to partnership criteria and performance. Distributors and value added resellers have access to management through objective incentives; whereas gold, silver and authorised channel partners (but not distributors) are eligible for sales performance incentives. The importance of incentives in the channel business model was further validated by Informant, In_4, "It [channel membership] is driven by incentives and competition; although it is very complex, it is better than developing just a partnership business model."

- Self-reinforcing mechanism: Thirdly, AlphaVendor and its ecosystem actors use a selfreinforcing mechanism to strengthen their partnership, focusing on trust, relationship, commitment and support. The following quotation highlights the focus on mutual trust within the ecosystem: "A lot of vendors, I have worked in the past, behave as if they were doing us a favour. But, with AlphaVendor, it is the other way around; they recognise our need for them, and also that our channel partners trust us to deliver the right results." (PDist)

Several actors in AlphaVendor's ecosystem echoed the importance of honesty and open communication in collaboration in the B2B context. However, a self-reinforcing mechanism is not without its challenges, especially when a new member joins the service ecosystem. This is because new members must establish relationships with other actors and test the 
financial and incentive mechanisms of AlphaVendor's ecosystem. For example, CP3 asserted the role of trust in the channel ecosystem, "massive trust is one of the key things that's part of this partnership. Without that trust, there's no partnership and ... this goes both ways".

Several partners highlighted the importance of vendor support in their business development. Informants in Stage 2 also stressed the importance of self-reinforcement in sustaining the channel business model, for example (In_1): "self-reinforcement is the most important when it comes to people, because that will increase the sustainability of business operation".

Although co-creation of value is evident in the AlphaVendor channel ecosystem, we also found several instances where value is co-destroyed, discussed in the following sections.

\subsection{Value co-destruction in B2B context}

\subsubsection{Actors' opportunism}

Using the transaction cost theory lens, we found opportunistic behaviour was widespread in partner interactions, especially pervasive in areas like the marketing development fund claim and provision process, provision of solutions and services in response to customer needs (project-level), customer relationship management, and partner/actor support mechanism.

Specifically, this research revealed that all the actors in AlphaVendor's ecosystem displayed opportunistic behaviour, which impacted partner relationships and diminished the value co-created. We summarise with evidence-quotations from the interviews (in Table 3) the impact of actors' opportunism on value co-destruction under three key themes: termination of relationship, conflict and business liquidation.

Theme 1, termination of relationship, highlights the breakdown of the partnership as a result of opportunistic behaviour. As discussed earlier, actors' capabilities in the form of resources are a fundamental building block for value co-creation. However, when actors adopted self-promoting strategies, this led to misuse of resources and value co-destruction (Theme 1.1).

One such example was the Marketing Development Fund (MDF), which is provided by the vendor to its distributor and channel partners to promote its products and services. However, several participants reported the misuse of funds. The actors' opportunistic behaviour leads to value co-destruction as follows: in the short-term it causes lose (for vendor) - win (for partners who misuse MDF) situation; but in the long-term it leads to a lose (no market development for vendor) - lose (no MDF for partners) situation.

There was also evidence of systemic lapse in honouring contractual promises (Theme 1.2). Opportunistic behaviour was evident in the areas of MDF and provision of solutions and services in response to customer needs. As detailed earlier, the channel governance mechanism is a fundamental block enabling value co-creation in the B2B context.

Further, when actors failed to abide by contractual agreements it led to the value codestruction as follows: in the short-term it created a win (for vendors who do not provide MDF) - lose (for partners who are unable to win customers) situation, and in the long-term it resulted in a lose (for vendors who lose customer and partner trust) - lose (for partners who are unable to service customers) situation. 
Table 3: Actors' opportunism and value co-destruction process

\begin{tabular}{|c|c|c|c|}
\hline Level 1 Coding & Level 2 Coding & Actors Involved & Indicative quotes \\
\hline \multirow[t]{2}{*}{$\begin{array}{l}\text { 1. Termination } \\
\text { of } \\
\text { partnership }\end{array}$} & $\begin{array}{ll}1.1 & \text { Misuse of } \\
& \text { resources }\end{array}$ & $\begin{array}{l}\text { Vendor - Channel } \\
\text { Partners }\end{array}$ & $\begin{array}{l}\text { "There's a lot of people [partners] that sign up to be a partner try to apply to take } \\
\text { marketing funds and never deliver anything" (CP2) } \\
\text { "There have been occasions where those [marketing] funds have been misused. } \\
\text { Sometimes that's just gone directly to the company's bottom line as a way of } \\
\text { making extra profit on a deal or over the course of the year." (AV_M1) } \\
\text { "Of course, they (partners) do. It is something called creative use of MDF" } \\
\text { (Comp_M1) } \\
\text { "Nobody [vendor] wants to give marketing money away because ... [of] having no } \\
\text { reward or no revenue back from MDF funding" (CP2) }\end{array}$ \\
\hline & $\begin{array}{l}1.2 \text { Dishonouring } \\
\text { contractual } \\
\text { promise }\end{array}$ & $\begin{array}{l}\text { Vendor - Partner } \\
\text { Distributor - } \\
\text { Channel Partners }\end{array}$ & $\begin{array}{l}\text { "We have a customer at the moment [who has] got a very large project which we } \\
\text { [have been] trying to win, but something else that we previously sold to them, } \\
\text { although totally unrelated to this project, isn't working as expected... And the } \\
\text { reason why [previous project] is not doing as expected, because the vendor [one of } \\
\text { AV's competitors] does not want to support" (CP3) } \\
\text { "When it was time for vendor to start delivering some activity and some MDF to } \\
\text { support [the contractual promise], it turned out [to be] a long process" (CP5) }\end{array}$ \\
\hline \multirow[t]{2}{*}{ 2. Conflict } & $\begin{array}{l}2.1 \text { Termination } \\
\text { of unwritten } \\
\text { commitment }\end{array}$ & $\begin{array}{l}\text { Channel Partners } \\
\text {-Partner } \\
\text { Distributor }\end{array}$ & $\begin{array}{l}\text { "When the vendor has marketing leads, they distribute [it] to its partners. The } \\
\text { partner goes, 'Oh that is a nice lead, I think actually we might do better with } \\
\text { another vendor' and they [channel partner] take it somewhere else" (CP3) } \\
\text { "Channel partner talks to a customer about solution services; but then the } \\
\text { distributor has also been talking to the customer about their range of services. It's } \\
\text { a problem that's not going to go away" (CP2) }\end{array}$ \\
\hline & 2.2 Loss of trust & $\begin{array}{l}\text { Vendor - Partner } \\
\text { Distributor - } \\
\text { Channel Partners }\end{array}$ & $\begin{array}{l}\text { "We would do work on a project, we provide demo, provide support with } \\
\text { quotations and eventually come up with the opportunity. But another [channel] } \\
\text { partner will be told [by the vendor] that they supply the deal" (CP1_M1) }\end{array}$ \\
\hline
\end{tabular}




\begin{tabular}{|c|c|c|c|}
\hline Level 1 Coding & Level 2 Coding & Actors Involved & Indicative quotes \\
\hline & & & $\begin{array}{l}\text { "Sales representatives [of the channel partner] go to the customer and say, 'Yes, of } \\
\text { course, we can get you 90\% discount', and then partner would [approach] us...but } \\
\text { we can't do it [offer that level of discount], and that reflects badly on us" (PDist) }\end{array}$ \\
\hline & $\begin{array}{l}2.3 \text { Role } \\
\text { contradiction }\end{array}$ & $\begin{array}{l}\text { Vendor - Partner } \\
\text { Distributor - } \\
\text { Channel Partners }\end{array}$ & $\begin{array}{l}\text { "We [distributor] are a certified services provider, and there's a bit of confusion } \\
\text { around when we should be promoting our services or when AlphaVendor should be } \\
\text { promoting their services; but obviously, we put a significant investment in } \\
\text { becoming a services partner, so we would want to take a lead on that!" (PDist) } \\
\text { "One of the things we [distributor] are looking to do on the process of training is } \\
\text { to become an authorised training centre for AlphaVendor" (PDist) } \\
\text { "Distributors should not be selling to end users, but they are selling services to end } \\
\text { users. And for us (channel partner) as a service company that's conflict" (CP2) } \\
\text { "We also want the distributor to develop competence in selling solutions, not just } \\
\text { shifting a box from vendor to channel partner" (Comp_M2) }\end{array}$ \\
\hline $\begin{array}{l}\text { 3. Business } \\
\text { liquidation }\end{array}$ & & $\begin{array}{l}\text { Vendor - Partner } \\
\text { Distributor - } \\
\text { Channel Partners }\end{array}$ & $\begin{array}{l}\text { "Unfortunately, I have been involved in a company that went into liquidation } \\
\text { because, the [distributor] withdrew...credit line and it became very difficult [for } \\
\text { the channel partner] to be able to trade, as a result the business had to go under" } \\
\text { (CP3) }\end{array}$ \\
\hline
\end{tabular}


The research found several references to conflict (Theme 2) between the ecosystem partners. Since membership to the channel ecosystem is not exclusive, several actors showed opportunistic behaviour that terminated unwritten commitments (Theme 2.1) leading to value co-destruction as follows. In the short-term it led to a lose (for vendors who provide a sales lead to partners) - win (for partners who take the lead to another vendor) situation, and in the long-term it caused a lose (for vendor and customers) - lose (for partners who are competing and potentially providing contradictory information) situation.

The study also found that actors' behaviour led to loss of trust, often due to misrepresentation of facts (Theme 2.2). In the short-term this resulted in a win (for vendors who pitched several partners against each other) - lose (for partners who invested significant effort, but could not sell the service/product) situation; and in the long-term it created a lose (for vendor and customers because promises were not kept) - lose (for distributors-partners who were unable to meet customer expectations) situation.

As explained earlier, actors' perceived value in the ecosystem played an important role in co-creating value; however, when actors contradicted Channel Handbook guidelines on roles and responsibilities (Theme 2.3) it created conflict. In the short-term it shaped a win (for vendors who pitched several partners against each other) - lose (for partners who invested significant effort, but could not sell the service/product) situation, and in the long-term it led to a lose (for vendor and customers because promises were not kept) - lose (for distributorspartners who were unable to meet customer expectations) situation.

Finally, this research found that opportunistic behaviour had a severe detrimental effect on a partner, whose business went into liquidation (Theme 3). Although, the actors acknowledged the importance of the channel governance mechanism and resource integration for value co-creation, when they adopted a self-centred and short-term finance-oriented strategy it resulted in value co-destruction for all the actors in the service ecosystem. Both in the short and the long-term it caused a lose (for vendor and distributor who lose a partner and potential business) - lose (for partners who are unable to stay solvent due to lack of access to credit) situation.

The themes identified in Table 4 were further validated with five informants in Stage 2 of the research. The informants highlighted the drivers for opportunistic behaviour, as experienced in their respective organisations and evidenced in research. The B2B ecosystem actors are under severe pressure to make more money, achieve higher margins, hit quarterly sales targets, focus on quantity (selling more) as opposed to quality (market development), demonstrate instant results, outshine competitors, with an emphasis on self-preservation rather than the health of the ecosystem.

\subsubsection{Technological disruptions and new business model challenges}

We note that ecosystem partners faced several challenges due to technological disruptions and new business models. For example, with the introduction of cloud computing, born-inthe cloud firms do not buy infrastructure from the enterprise vendors, which fundamentally challenges AlphaVendor's core business. Vendors are now in a race to meet demands in the digital age, and pressed to demonstrate their ability to respond with suitable products and services. Thus, opportunism is employed by ecosystem actors to reduce uncertainty and transaction cost. 
Digital transformation in the form of the Internet-of-Things (IOT), blockchain, cloud, etc. requires businesses to reconsider their value propositions and business models. For example, as a competitor of AlphaVendor said, "if you buy as a service, there is no need for inventory, and if you pay 'per use', there is no need for finance" (Comp_M1). Similarly, another participant noted, "If distributors are suffering, we (vendor) are suffering" (Comp_M2).

Thus, digital disruptions and resultant business model changes are challenging all the actors in the channel ecosystem. For example, partners who focus on one-off project business, i.e. CAPEX (capital expenditure), are struggling to compete with born-in-the-cloud partners that focus on OPEX (operating expense), i.e. providing service on a monthly or annual subscription basis. As AV_M1 noted:

Born in the cloud partners would aggregate cloud services by pulling some resources from Azure, others from Amazon Web Services or from Salesforce, none of that needs infrastructure from AlphaVendor. AlphaVendor wants to sell infrastructure to cloud providers to run their applications on it, but, born in the cloud scenario is very difficult to work with those partners. (AV_M1)

Thus, service ecosystem partners must shift their organisational model to stay relevant in the rapidly changing landscape. As explained earlier, in the B2B context vendors have traditionally gone to market only through their channels and struggled to motivate their ecosystem partners to bring in business on a continuing basis (AV_M1). As the vendorpartner agreement is not exclusive, the distributors-partners are free to sell the products of any vendor. Thus, vendors struggle to incentivise partners and command loyalty. As Comp_M1 noted, "the most common problem that every vendor has with its channel is - how can I make sure my channel is loyal to me, and that they [partners] favour my solution versus the competition." Service ecosystems in the ICT sector operate in a crowded and global market place, where the network partners' quest to build capabilities, especially technologybased, and enhance perceived value leads to self-serving behaviour.

The partner firms (CP1, CP2 and CP3) also raised a challenge associated with the vendor's approach to selling an IT product; while their “customers are looking for a solution", most vendors in the enterprise market are interested in the product, but partners "also need their (vendor's) expertise and support to create and deliver the solutions, and it is sometimes difficult to convince them of this" (CP2). Thus, the ecosystem actors must work together to bundle products and services to meet customer needs; this requires all the actors to exchange resources and deliver their part of the value in the relationship.

\section{Discussion and contributions}

We explore how an ICT hardware enterprise vendor and its ecosystem partners co-create and co-destroy value in the B2B context. Using an in-depth case study, we find that vendor organisations invest in their channel ecosystem partners, who deliver products and services to customers. We find that value is co-created through actors' capabilities, both resources and perceived value, vendor's approach to achieving strategic benefit, and a channel governance mechanism. However, the incentive-rewards channel partnership mechanism and resource sharing lead to a significant predicament, as actors display opportunistic behaviour. Although vendor-distributor-partner alliances thrive in the ICT sector, all actors reported both satisfaction and dissatisfaction with each other's behaviour. Using the ecosystem and 
transaction cost theory lenses, we investigate and find both partner satisfaction due to collaborative behaviour and dissatisfaction due to opportunistic behaviour in the service ecosystem (Laamanen and Skalen, 2015).

Firstly, value co-creation happens when alliance partners share resources and support value propositions. Successful alliances show strong governance strategies, such as contractual agreement, membership selection, incentives-rewards programmes and a selfreinforcing mechanism. Channel policies play a fundamental role in creating an ecosystem that facilitates value co-creation. The vendor's perceived value in the ecosystem is closely linked to price and reliability of the products, $R \& D$ capability, higher margins for distributors and channel partners, and knowledge transfer. Successful vendors display novel use of operant resources (Vargo and Lusch, 2016). We found that our case organisation, AlphaVendor, has developed channel policies not only to govern alliances but also to facilitate value co-creation.

Secondly, AlphaVendor showed ambition to challenge competitors and create a stronger brand through novel approaches like the development of a training academy to attract new actors to its ecosystem. Thus, AlphaVendor demonstrated innovative approaches to the B2B alliance in order to achieve strategic benefits (Vargo and Lusch, 2016; Waseem et al., 2018).

Some of the challenges identified in AlphaVendor's ecosystem, such as motivating partner loyalty, are related to developing alliance capability and culture (Luvison and de Man, 2015; Bagheri et al., 2019). We noted that a well-developed governance structure and processes facilitate coordination (Gulati et al., 2012; Chatman et al., 2014). In addition, incentivesrewards (not necessarily monetary benefits), such as privileged access to information or involvement in important decisions played an importance role in VCC (Gulati et al., 2012).

The vendor-distributor-channel partner behaviour undermines the overall enterprise business go-to-market model, and strengthens the strategic need for collaboration. The literature (Gulati, 1998; Park and Ungson, 2000; Dacin et al., 2007; Sarker et al. 2012; Leclercq et al., 2016; Kolbjornsrud, 2017) has highlighted the significance of governance, membership restriction and trust between partners for collaboration and co-creation. In addition, we find that our case organisation used two novel strategies. Firstly, AlphaVendor adopted a tiered approach to partnership: where the distributors are Tier 1, while partners and the channel partners are Tier 2. This approach has two important functions: it reduces coordinative complexity and serves as a motivational mechanism (Gulati et al., 2012). Secondly, AlphaVendor used a team agreement as a basis for loosely coupled relationships (Lusch and Nambisan, 2015), where partners join a channel ecosystem for specific opportunities. We therefore highlight the importance of tiering approach and team agreements for alliances in the B2B context.

Additionally, value co-destruction happens due to conflictual interactions resulting in winlose or lose-lose outcomes, as fuelled by actors' opportunistic behaviour. Our research shows that conflicting interests between alliance actors, driven by the motivation to minimise transaction cost, can affect performance negatively (Christoffersen, 2013), fuel opportunistic behaviour, reduce the alliance's ability to co-create (Lacity and Willcocks, 1998; Sarker et al., 2012), and lead to value co-destruction (Vafeas et al., 2016; Jarvi et al., 2018).

Our in-depth case study research highlights practices of both strong- (withdrawing credit line), and weak-forms (dishonouring oral promises) of opportunism, which result in value co- 
destruction (Laamanen and Skalen, 2015; Chowdhury et al., 2016). For example, a strongform of opportunism was evident when a distributor withdrew the credit line from a channel partner, who went into liquidation. We also noted several weak-forms of opportunism, for example the unavailability or misuse of marketing development funds resulted in the loss of key resources for some actors, an indicator of value co-destruction (Smith, 2013). We thus find support for the argument that alliance actors do show opportunistic behaviour, which ultimately weakens the foundation for collaboration (Williamson, 1985; Luo, 2006).

Clohessy et al. (2017: 14) summarise the new opportunities afforded by technological advances: "cloud technology provides IT service provider both business operational value and economic value benefits previously not afforded to them in the traditional mode of IT service provision". We contribute to this growing literature by investigating and finding that technological advances and new business models present a huge challenge for some alliance partners in the B2B context. For example, new business models need to evolve to meet customer demand for services (OPEX) as against traditional products (CAPEX). Further, vendors who lack the capability or resources to respond to technological advances will lose market share (Park et al., 2014). This is because they are being challenged not only by their born-in-the-cloud competitors, but also by their distributor and channel partners who have cloud technology capabilities. This suggests that business model innovation is an option for those affected by new technology trends. As the conception of business model becomes ever more an ecosystem level subject (Kohtamaki and Rajala, 2016), prevailing logic of resource integration as a central means for connecting people and technology within and among service systems (Vargo et al., 2012) could transform the organisational value creation strategies. We have consolidated the determinants for value co-creation and co-destruction in the B2B context in Figure 4.

\subsection{Theoretical implications}

We find evidence that value is co-created by multiple actors in a service ecosystem through actors' capabilities and perceived value, vendor's approach to achieving strategic benefit, and strong channel governance. However, as the actors are interdependent in a service ecosystem, self-serving behaviour can destroy value. Opportunism is widely practised and is multidirectional in vendor-distributor-partner interactions. Thus, value co-destruction can co-exist alongside value co-creation in the B2B context (Prior and Marcos-Cuevas, 2016).

The strategic motivation to maximise value is evident in successful alliances, where value co-creation is evident through resource integration, partner loyalty and incentives, trust and governance (Sarker et al., 2012). In contrast, the motivation to minimise transaction costs can lead to conflict amongst alliance partners (Laamanen and Skalen, 2015). This theoretical departure towards the possibility of negative outcomes in a B2B alliance shows bounded rationality and opportunism (Das, 2006).

We contribute to the literature on VCD, reporting the important role of opportunistic behaviour in the generation of negative outcomes for alliance partners, where opportunism hampers the relationship between ecosystem partners in the long-term, and destroys the value creation capability of the alliance (Williamson, 1985; Luo, 2006). We argue that there is always scope for the coexistence of value co-creation and value co-destruction in an alliance (Prior and Marcos-Cuevas, 2016). 


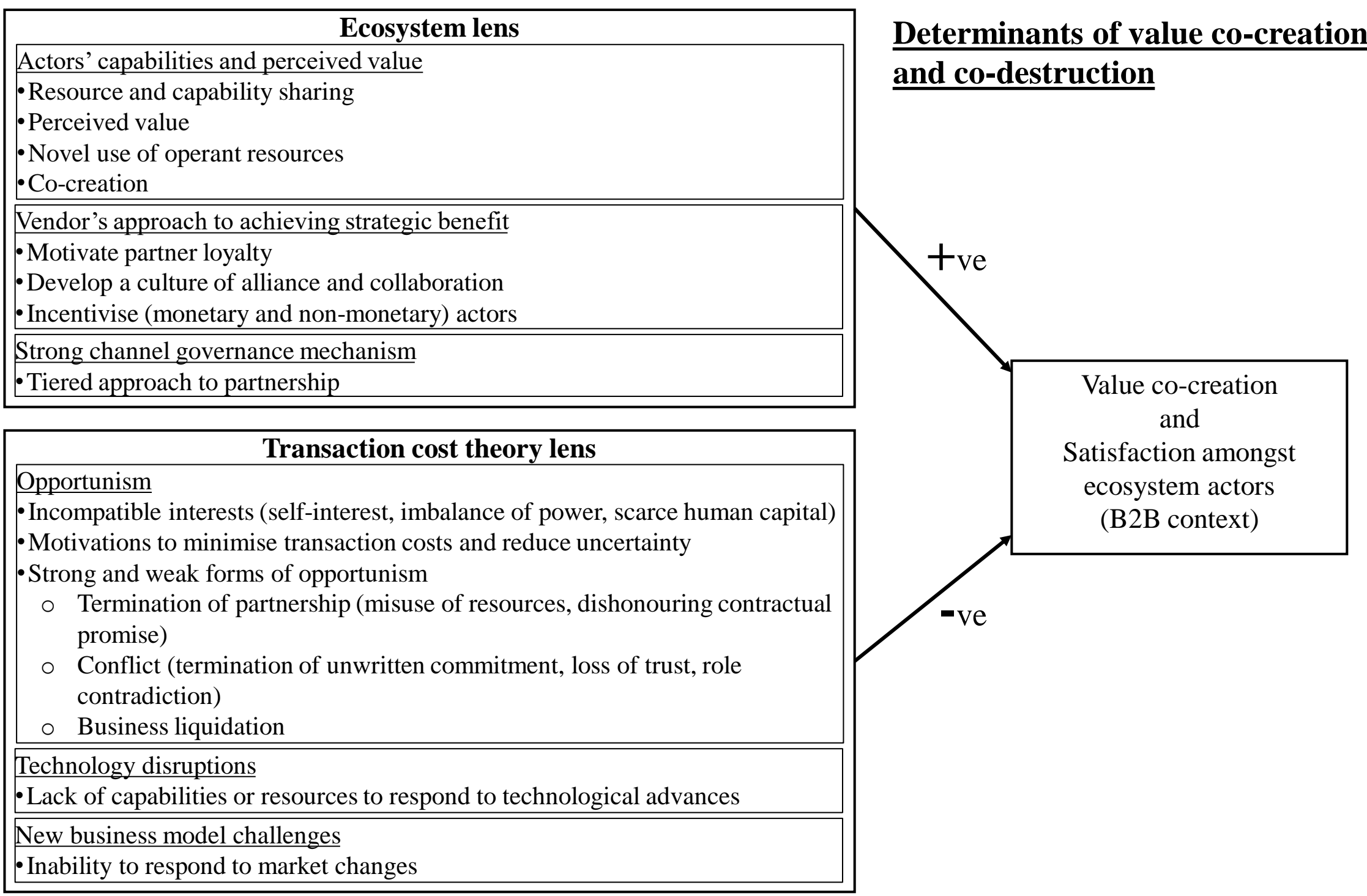

Figure 4: Determinants of value co-creation and co-destruction in the B2B context 
The service-dominant logic literature has historically focused on the factors that enable value co-creation. However, in recent years there has been a progression to incorporate the conflicts between alliance partners (e.g. Makkonen and Olkkonen, 2017). This has opened avenues to research the effect of the conflictual side of value co-creation and devise strategies to avoid such conflict. In response, we investigate the factors that lead to value co-creation and co-destruction in a unique case involving a vendor and its ecosystem partners (distributors, channel partners, customers, competitors) in the B2B context.

In fact, Brodie et al. (2019) identified the need for advancement of service-dominant logic theory using multifaceted insights. Firstly, dominant literature in transaction cost economics focuses on the merit of a two-party exchange model in vertical integration (KarimiAlaghehband et al., 2011; Ketokivi and Mahoney, 2016). Our research goes further and highlights a three-party exchange utilising vendor-distributor-channel partner interaction. Secondly, existing service-dominant logic research focuses on positive outcomes of value cocreation process, but provides limited understanding of value co-destruction process. In response, this study offers the determinants of value co-creation and co-destruction. It presents multidimensional insights into facets of technology, market and societal phenomena that inform theoretical perspectives on contemporary practices in enterprise business.

\subsection{Managerial implications}

ICT ecosystems are dynamic and fiercely competitive. Alliance partners, thus, need to evaluate the strategic benefits of collaboration, knowledge sharing, learning, trust building, market expansion and technology sharing. This is because partners' opportunistic behaviour as driven by transaction cost economies leads to value diminishment. All ecosystem actors are seeking to develop capabilities, exhibit knowledge differentiators, demonstrate technology leadership, reduce uncertainty and respond to new business model challenges thus causing value co-destruction.

The concept of service ecosystems highlights the significant role of technology (Lusch, 2011) in value co-creation. However, this study suggests that such technologies could offer a significant challenge to co-create value in enterprise business ecosystems. This suggests the dual role of technology in value co-creation as facilitator as well as challenger for the traditional business model (e.g. CAPEX). This insight unveils how new technologies enabled new forms of business model (e.g. OPEX) that challenges B2B context of enterprise business. This opens up new debate in the B2B and business model literature about the challenges, role and survival of enterprise vendors, who go to market through channels only; especially in the era of Amazonisation of enterprise market (Cortez and Johnston, 2017).

ICT vendors in the B2B service ecosystem fundamentally rely on alliance partners (including customers) to offer innovative products and services. The ecosystem functions successfully when value is co-created and there is satisfaction amongst the ecosystem actors. ICT vendor managers in B2B service ecosystems must focus on three aspects (the determinants of value co-creation): firstly, on ecosystem actors' capabilities and perceived value, secondly, on vendors' approach towards achieving strategic benefit and finally, on strong channel governance mechanism. Value co-creation happens when all partners contribute resources, and the actors have a perceived value in the alliance. There is need for innovative use of operant resources and sharing of partners' capabilities. Secondly, since 
vendor-partner agreements are not exclusive, the vendors must motivate partner loyalty and develop a culture of alliance and collaboration using both monetary and non-monetary incentives. Finally, strong channel governance mechanism like tiered approach to partnership are beneficial in co-creating value.

However, ICT ecosystems show increased coopetition, blurring of industry boundaries, tensions and dynamic relationship between ICT vendors. Further, ICT ecosystems have difficulties in enabling collaboration across the network partners. Thus, managers must acknowledge that value can be co-destructed in an alliance. The determinants of value codestruction are: incompatible interests, motivations to minimise transaction costs and reduce uncertainty, and strong- and weak-forms of opportunism. Further, an alliance partner's lack of capability or resource to respond to technological advances also leads to value co-destruction. Finally, digital transformation requires organisations to reconsider their value propositions and business models, especially in the current global and servitised market. However, actor's inability to respond to market changes also leads to co-destruction and dissatisfaction amongst B2B ecosystem partners.

Thus, evidence from our case organisation exemplifies how resource-scarce organisations can adopt a co-creation approach to utilise the channel ecosystem to reach new customers and markets. We provide managers with conceptual clarity on the factors that enable and inhibit VCC. Managers can also learn how the changing business from product selling (CAPEX) to solutions selling (OPEX) can be achieved by optimising new technologies and resources from their ecosystem partners. The findings of this research provide a valuable reference list for alliance partners to assess their practices and strengthen their business models.

\section{Conclusion, limitation and future research}

To summarise, B2B alliances are driven by the motivations to maximise strategic value and minimise transaction costs. Thus, there is scope for both value co-creation and value codestruction to coexist in an alliance. We contribute to the VCC literature on two fronts. First, through the ecosystem lens, we find that actors' capabilities (resources and perceived value) and channel governance mechanism enable value co-creation. We highlight the benefits of the tiering approach, non-monetary incentives-rewards schemes, and team agreements (as against contractual agreements) for loosely coupled relationships. Second, through the transaction cost theory lens we report that both strong- and weak-forms of opportunistic behaviour exist in an alliance, which can lead to value co-destruction in the form of termination of the relationship, conflict and business liquidation. Further, technological innovations in the current digital economy are challenging vendors, who are required to develop novel business models to meet ever-changing customer demands. This research is, therefore, more encompassing because it explores factors that lead to both value co-creation and value co-destruction.

As discussed in the AlphaVendor case, instances of vendors', distributors' as well as channel partners' practices of opportunism lead to co-destruction of value; as supported by transaction cost theory. It is obvious that a destructive process will affect the recipient of any benefits. The rationale for this claim is that while service-dominant logic already incorporates who should co-create value, it should also include who can co-destroy value and how they can do it. 


\subsection{Limitations and future research direction}

The findings of our research should be viewed in light of the following limitations: the theoretical underpinning of this research, the methodology adopted, and the case study used for this study. We believe that more work is needed to validate the findings in a wider context, where researchers can assess different co-creation practices and explore the effects of opportunism on such practices. This is also warranted from the perspective of generalisability of the research findings to other contexts.

We have identified some future research opportunities. Firstly, researchers could study the effect of actors' opportunism in the B2C and open innovation contexts. Secondly, future research could investigate the impact of customers' opportunistic behaviour on the cocreation practices of both the supply (vendor-distributor-partner) and demand (customer) sides. Thirdly, future studies could investigate our finding that value is co-destroyed by multiple actors in different sectors. Finally, more work is needed to understand why alliances succeed, despite actors' motivation to minimise transaction costs, using other theoretical viewpoints like dynamic capability.

\section{References}

Aarikka-Sternroos, L. \& Ritala, P. (2017). Network management in the era of ecosystems: Systematic review and management framework. Industrial Marketing Management, 67, 23-36.

Aarikka-Stenroos, L., Sandberg, B. \& Lehtimaki, T. (2014). Networks for the commercialization of innovations: A review of how divergent network actors contribute. Industrial Marketing Management, 43, 365-381.

Akaka, M. A. and Vargo, S. L (2014). Technology as an operant resource in service (eco) systems. Information systems and E-Business Management. 12, 367-384

Arnould, E. J. (2014). Rudiments of a value praxeology. Marketing Theory, 14, 129-33.

Ashok, M. (2018). Role of Digitisation in Enabling Co-creation of Value in KIBS Firms. In International Conference on Informatics and Semiotics in Organisations (pp. 145-154). Springer.

Ashok, M., Narula, R. and Martinez-Noya, A., (2014). End-user collaboration for process innovation in services: The role of internal resources. UNU-MERIT Working Papers; No. 019.

Ashok, M., Narula, R. \& Martinez-Noya, A., (2016). How do collaboration and investments in knowledge management affect process innovation in services?. Journal of Knowledge Management, 20(5), 1004-1024.

Ashok, M., Day, M. \& Narula, R., (2018). Buyer (dis) satisfaction and process innovation: the case of information technology services provision. Industrial Marketing Management, $68,132-144$

Bagheri, S., Kusters, R.J. \& Trienekens, J. (2019). Customer knowledge transfer challenges in a co-creation value network: Toward a refernce model. International Journal of Information Management, 47, 198-214.

Basole, R.C., Park, H. and Barnett, B.C., 2015. Coopetition and convergence in the ICT ecosystem. Telecommunications Policy, 39(7), pp.537-552.

Brodie, R. J., Lobler, H. \& Fehrer, J.A. (2019). Evolution of service-dominant logic: Towards a paradigm and metatheory of the market and value co-creation?. Industrial Marketing Management, 79, 3-12.

Boyatzis, R.E. (1998). Transforming qualitative information: Thematic analysis and code development. Sage. 
Braun, V. \& Clarke, V. (2006). Using thematic analysis in psychology. Qualitative research in psychology, 3(2), 77-101.

Bryman, A. (2016). Social Research Methods. Oxford: Oxford University Press.

Cabiddu, F., Moreno, F. Sebastiano, L. (2019). Toxic collaborations: Co-destroying value in the B2B context. Journal of Service Research. 22 (3), 241-255.

Cantrill, J. A., Sibbald, B. \& Buetow, S. (1996). The Delphi and nominal group techniques in health services research. International Journal of Pharmacy Practice, 4, 67-74.

Chatman, J. A., Caldwell, D. F., O'reilly, C. A. \& Doerr, B. (2014). Parsing organizational culture: how the norm for adaptability influences the relationship between culture consensus and financial performance in high-technology firms. Journal of Organizational Behavior, 35, 785-808.

Chowdhury, I. N., Gruber, T. \& Zolkiewski, J. (2016). Every cloud has a silver lining Exploring the dark side of value co-creation in B2B service networks. Industrial Marketing Management, 55, 97-109.

Chou, E. Lin, C. Huang, H. (2016). Fairnes and devotion go far: integrating online justice and value co-creation in virtual communities. International Journal of Information Management, 36 (1), 60-72.

Christoffersen, J. (2013). A Review of Antecedents of International Strategic Alliance Performance: Synthesized Evidence and New Directions for Core Constructs. International Journal of Management Reviews, 15, 66-85.

Chuang, S. \& Lin, H. (2015). Co-creating e-service innovations: Theory, practice, and impact on firm performance, International Journal of Information Management, 35 (3), 277 291.

Clohessy, T., Acton, T. \& Morgan, L. (2017). The impact of cloud-based digital transformation on IT service providers: Evidence from focus groups. International Journal of Cloud Applications and Computing, 7, 1-19.

Cortez, R. M. and Johnston, W. (2017). The future of B2B marketing theory: A historical and prospective analysis. Industrial Marketing Management. 66. 90-102.

Creswell, J. W. (2009). Research design; qualitative, quantitative, and mixed methods approaches, London, Sage publications.

Dacin, M. T., Oliver, C. \& Roy, J. (2007). The legitimacy of strategic alliance: An institutional perspective. Strategic Management Journal, 28, 169-187.

Das, T.K., 2006. Strategic alliance temporalities and partner opportunism. British Journal of Management, 17(1), pp.1-21.

De Man, A. and Luvison, D. (2019). Collaborative business models: Aligning and operationalizing alliances. Business Horizons, 62, 473-482.

Echeverri, P. \& Skalen, P. (2011). Co-creation and co-destruction: A practice-theory based study of interactive value formation. Marketing Theory, 11, 351-373.

Edvardsson, B., Skalen, P. \& Tronvoll, B. (2012). Service systems as a foundation for resource integration and value co-creation. Review of Marketing Research, 9, 79-126.

Eisenhardt, K. M. \& Graebner, M. E. (2007). Theory building from cases: Opportunitees and challenges. Academy of Management Journal, 50, 25-32.

Ertimur, B. \& Venkatesh, A. (2010). Opportunism in co-production: Implications for value cocreation. Australasian Marketing Journal, 18, 256-263.

Farquhar, J. D. \& Robson, J. (2017). Selective demarketing: When customers destroy value. Marketing Theory, 17.

Gemser, G. \& Perks, H. (2015). Co-Creation with Customers: An Evolving Innovation Research Field. Journal of Product Innovation Management, 32, 660-665.

Gronroos, C. \& Voima, P. (2013). Critical service logic: making sense of value creation and co-creation. Journal of the Academyof Marketing Science, 41, 133-150. 
Gulati, R. (1998). Alliances and Networks. Strategic Management Journal, 19, 293-317.

Gulati, R., Puranam, P. \& Tushman, M. (2012). Meta-organization design: rethinking design in interorganizational and community contexts. Strategic Management Journal, 33, $571-586$.

Hartley, J. (2004). Case study research. In: Cassell, C. \& Symon, G. (eds.) Essential Guide to Qualitative Methods in Organizational Research. London Sage Publications Ltd.

Hietanen, J., Andehn, M. \& Bradshaw, A. (2017). Against the implicit politics of servicedominant logic. Marketing Theory, 1-19.

Ind, N., Iglesias, O. \& Schultz, M. (2013). Building Brands Together: Emergence and outcomes of co-creation California Management Review, 55, , 5-26.

Jap, S. D., Robertson, D. C., Rindfleisch, A. P., \& Hamilton, R. (2013). Low-stakes opportunism. Journal of Marketing Research, 50(2), 216-227.

Jha, S.K., Pinsonneault, A. and Dubé, L., 2016. The evolution of an ICT platform-enabled ecosystem for poverty alleviation: The case of eKutir. MIS Quarterly, 40(2), pp.431445.

Karimi-Alaghehband, F., Rivard, S., Wu, S. \& Goyette, S. (2011). An assessment of the use of Transaction Cost Theory in information technology outsourcing. The Journal of Strategic Information Systems, 20, 125-138.

Ketokivi, M. \& Mahoney, J. T. (2016). Transaction cost economics as a constructive stakeholder theory. Academy of Management Learning \& Education, 15, 123-138.

Ketokivi, M. \& Mahoney, J. T. (2017). Transaction Cost Economics as a Theory of the Firm, Management, and Governance Oxford Research Encyclopedia of Business and Management.

Kohtamaki, M. \& Rajala, R. (2016). Theory and practice of value co-creation in B2B systems. Industrial Marketing Management, 56, 4-13.

Kolbjørnsrud, V. (2017). Agency problems and governance mechanisms in collaborative communities. Strategic Organization, 15, 141-173.

Jarvi, H., Kahkonen, A. \& Torvinen, H. (2018). When value co-creation fails: Reasons that lead to value co-destruction. Scandinavian Journal of Management, 34, 63-77.

Laamanen, M. \& Skalen, P. (2015). Collective-conflictual value co-creation: A strategic action field approach. Marketing Theory, 15, 381-400.

Lacity, M. \& L. Willcocks (1998). An Empirical Investigation of Information Technology Sourcing Practices: Lessons from Experience. MIS Quarterly. 22(3), 363-408.

Leclercq, T., Hammedi, W. \& Poncin, I. (2016). Ten years of value cocreation: An integrative review. Recherche et Applications en Marketing, 31, 26-60.

Lilien, G. L. (2016). The B2B knowledge gap. International Journal of Research in Marketing, 33(3), 543-556.

Luo, Y. (2006). Opportunism in inter-firm exchanges in emerging markets. Management and Organization Review, 2, 121-147.

Lusch, R.F. (2011). Reframing supply chain management: A service-dominant logic perspective. Journal of Supply Chain Management. 47,1 14-18.

Lusch, R. F. \& Nambisan, S. (2015). Service Innovation: A Service-Dominant Logic Perspective. MIS Quarterly, 39, 155-175.

Luvison, D. \& De Man, A. (2015). Firm performance and alliance capability: the mediating role of culture. Management Decision, 53, 1581-1600.

Maglio, P. (2017). New Directions in Service Science: Value Cocreation in the Age of Autonomous Service Systems. Service Science, 9, 1-2.

Makkonen, H. \& Olkkonen, R. (2017). Interactive value formation in interorganizational relationships: Dynamic interchange between value co-creation, no-creation, and codestruction Marketing Theory, 17. 
Martinez-Noya, A. \& Narula, R. (2018). What more can we learn from R\&D alliances? A review and research agenda. BRQ Business Research Quarterly.

Masten, S. E. (1988). Equity, Opportunism, and the Design of Contractual Relations. Journal of Institutional and Theoretical Economics, 144, 180-95.

McColl-Kennedy J. R., Vargo S. L., Dagger T. S.,. Sweeney J. C, van Kasteren Y. (2012), Health Care Customer Value Cocreation Practice Styles. Journal of Service Research, 15 (4), pp. 370-389

Mele, C., Russo-Spena, T. \& Colurcio, M. (2010). Co-creating value innovation through resource integration. International Journal of Quality and Service Sciences, 2, 60-78.

Moore, J. F. (1996). The death of competition: Leadership \& strategy in the age of business ecosystems, New York, Harper Business.

Mustak, M., Jaakkola, E. \& Halinen, A. (2013). Customer participation and value creation: a systematic review and research implications. Managing Service Quality: An International Journal, 23, 341-359.

Nam, K., Baker, J., Ahmad, N., \& Goo, J. (2018). Dissatisfaction, Disconfirmation, and Distrust: an Empirical Examination of Value Co-Destruction through Negative Electronic Word-of-Mouth (eWOM). Information Systems Frontiers.

Neghina, C., Caniels, M. C. J., Bloemer, J. M. M., \& Van Birgelen, M. J. H. (2015). Value cocreation in service interactions: Dimensions and antecedents. Marketing Theory, 15, 221-242.

Noordhoff, C. S., Kyriakopoulos, K., Moorman, C., Pauwels, P. \& Dellaert, B. (2011). The Bright Side and Dark Side of Embedded Ties in Business-to-Business Innovation. Journal of Marketing, 75, 34-52.

Ostrom, A. L., Parasuraman, A., Bowen, D. E., Patricio, L. \& Voss, C. A. (2015). Service Research Priorities in a Rapidly Changing Context. Journal of Service Research, 18, 127-159.

Park, S. H. \& Ungson, G. R. (2001). Interfirm Rivalry and Managerial Complexity: A Conceptual Framework of Alliance Failure. Organization Science, 12, 37-53.

Park, B.J., Srivastava, M.K. \& Gnyawali, D.R. (2014). Impact of coopetition in the alliance portfolio and coopetition experience on firm innovation. Technology Analysis \& Strategic Management, 26(8), 893-907.

Ple, L. (2017). Why do we need research on value co-destruction?. Journal of Creating Value. 3(2): $1-8$.

Prior, D. D. \& Marcos-Cuevas, J. (2016). Value co-destruction in interfirm relationships: The impact of actor engagement styles. Marketing Theory, 1-20.

Ramaswamy, V. \& Gouillart, F. (2010). The Power of Co-Creation: Build it with them to boost growth, productivity, and profits. London, Free Press.

Ramaswamy, V. \& Ozcan, K. (2018). What is co-creation? An interactional creation framework and its implications for value creation. Journal of Business Research. 84, $196-205$.

Rindfleisch, A. (2019). Transaction cost theory: past, present and future. AMS Review.

Ritala, P., Agouridas, V., Assimakopoulos, D. and Gies, O., 2013. Value creation and capture mechanisms in innovation ecosystems: a comparative case study. International Journal of Technology Management, 63(3-4), pp.244-267.

Robson, C. (2002). Real World Research. Oxford Blackwell.

Saarijärvi, H., Kannan, P. and Kuusela, H. (2013). Value co-creation: theoretical approaches and practical implications. European Business Review, 25(1), pp. 6-19.

Sandelowski, M. (1998). Focus on Qualitative Methods: The Call to Experts in Qualitative Research. Research in Nursing \& Health, 21, 467-471. 
Sarker, S., Sarker, S., Sahaym, A. \& Bjorn-Andersen, N. (2012). Exploring value cocration in relationships between an ERP vendor and its partners: A revelatory case study. MIS Quarterly, 36, 317-338.

Senyo, P.K., Liu, K. and Effah, J., 2019. Digital business ecosystem: Literature review and a framework for future research. International Journal of Information Management, 47, pp.52-64.

Skålén, P., Pace, S. \& Cova, B. (2015). Firm-brand community value co-creation as alignment of practices. European Journal of Marketing, 49, 3/4, 596-620.

Smith, A. M. (2013). The value co-destruction process: a customer resource perspective. European Journal of Marketing, 47, 1889 - 1909.

Spohrer, J. C. (2011). On looking into Vargo and Lusch's concept of generic actors in markets, or "It's all B2B ... and beyond!". Industrial Marketing Management, 40, 199-201.

Spohrer, J. \& Maglio, P. (2010). Service science: Toward a smarter planet, New York, Wiley $\&$ Sons.

Stuckey, H. L.(2015). The second step in data analysis: Coding qualtiative research data. Journal of Social Health and Diabetes. 3,1, 7-10.

Tommasetti, A., Troisi, O. and Vesci, M. (2017). Measuring customer value co-creation behavior. Journal of Service Theory and Practice, Vol. 27 No. 5, pp. 930-950.

Thomas, L. \& Autio, E. (2012). Modeling the ecosystem: A meta-synthesis of ecosystem and related literatures. DRUID CBS. Copenhagen, Denmark.

Uppström, E. \& C. Lönn (2017). Explaining value co-creation and co-destruction in egovernment using boundary object theory. Government Information Quarterly, 34: 406-420.

Vafeas, M., Hughes, T. \& Hilton, T. (2016). Antecedents to value diminution: A dyadic perspective. Marketing Theory, 1-23.

Vargo, S. L., Akaka, M. A. \& Vaughan, C. M. (2017). Conceptualizing Value: A Servcieecosystem view. Journal of Creating Value. 3(2), 117-124.

Vargo, S. L. \& Lusch, R. F. (2004). Evolving to a new dominant logic for marketing. Journal of Marketing, 68, 1-17.

Vargo, S. L. \& Lusch, R. F. (2011). It's All B2B ... and Beyond: Toward a System Perspective of the Market. Industrial Marketing Management, 40, 181-7.

Vargo, S. L. \& Lusch, R. F. (2016). Institutions and axioms: an extension and update of servicedominant logic. Journal of the Academy of Marketing Science, 44, 5-23.

Vargo, S. L., Lusch, R. F. \& Akaka, M. A. (2010). Advancing service science with servicedominant logic: clarifications and conceptual development, New York Springer.

Waseem, D., Biggemanna, S. \& Garrya, T. (2018). Value co-creation: The role of actor competence. Industrial Marketing Management, 70, 5-12.

Wathne, K. H. \& Heide, J. B. (2000). Opportunism in interfirm relationships: Forms, outcomes, and solutions. Journal of Marketing, 64, 36-51.

Williamson, O. E. (1985). The economic institutions of capitalism, New York, Free Press.

Williamson, O. E. (2007). Transaction Cost Economics: An Introduction. Economics Discussion Papers, No 2007-3, Kiel Institute for the World Economy.

Yigitbasioglu, O. (2014). Modelling the Intention to Adopt Cloud Computing Services: A Transaction Cost Theory Perspective. Australasian Journal of Information Systems 18, 193-210.

Yin, R. K. (2014). Case study research: Design and methods London, Sage. 